\title{
RELATIONSHIP BETWEEN MANAGERS' POLITICAL BEHAVIOR IN PERFORMANCE APPRAISAL SYSTEMS AND PERSONAL OUTCOMES
}

\author{
Azman Ismail \\ Faculty of Economics \& Management, Universiti Kebangsaan Malaysia, \\ 43600 Bangi, Selangor Darul Ehsan. MALAYSIA \\ Email: azisma08@gmail.com \\ Nur Safina Mohd Raduan \\ Faculty of Defence \& Management Studies, Defence National University of Malaysia, \\ Sungai Besi Camp. 57000 Kuala Lumpur, MALAYSIA \\ Email: nursafina_2908@yahoo.com
}

\begin{abstract}
This study was undertaken to investigate the correlation between managers' political behavior in performance appraisal systems and personal outcomes using self-reported questionnaires gathered from employees who have worked in a defence based university, Malaysia. The outcomes of stepwise regression analysis showed that motivational and punishment motives did act as important determinants of job satisfaction, but motivational and punishment motives did not act as important determinants of job turnover in the organizational sample. This study further provides discussion, implications and conclusion.
\end{abstract}

Keywords:Managers' political behavior, personal outcomes.

\begin{abstract}
Abstrak
Penelitian ini dilakukan untuk mengukur hubungan antara perilaku politis manajer dalam sistem penilaian prestasi dengan kelakuan individu menggunakan survei yang telah dikumpulkan dari pekerja di sebuah universitas berdasarkan pertahanan di Malaysia. Hasil analisis regresi bertahap menunjukkan bahwa motif motivasional dan hukuman berkemampuan untuk bertindak sebagai peramal yang penting kepada kepuasan kerja, tetapi motif motivasi dan hukuman tidak berkemampuan untuk bertindak sebagai peramal yang penting kepada keinginan untuk berhenti dalam sampel organisasional. Kemudian, makalah ini memberikan diskusi, implikasi dan kesimpulan.
\end{abstract}

Kata kunci: Perilaku politis manajer, kelakuan individu.

\section{INTRODUCTION}

Performance appraisal is a central function of strategic human resource development and management (Ismail et al., 2011, 2012b; Thurston \& McNall, 2010). In organizations, it is often viewed as a cyclical process where formal appraising methods are designed by employers to yearly assess and develop employee performance (Boswell \& Boudreau, 2002; Ismail et al., 2011, 2012b; Poon, 2003a, 2003b, 2004). Traditionally, many performance appraisal systems are designed dependent very much on cognitive models, which emphasize on quantifiable criteria as important guidelines to measure and determine performance scores to employees. For example, behavior and outcomes oriented rating methods are important cognitive based performance appraisal (Aminuddin, 2008; Dessler,
2005) where these methods are widely used by management to resolve routine human resource management functions, such as retain or terminate staff service, promote and determine staff salary (Cook \& Crossman, 2004; Fletcher, 2001, 2002; Tahir Suliman, 2007).

A recent research in performance management literature highlights that effectiveness of a cognitive based performance appraisal processes and outcomes is highly recognized when it is used to assess the performance of routine, structured and unambiguous job. Conversely, the effectiveness of a cognitive based performance appraisal processes and outcomes is questionable if it employed to measure the performance of unstructured, unpredictable and uncertain job. Alternatively, many managers have shifted their paradigms from a cognitive based performance appraisal to political behavior based performance 
appraisal in order to decrease the mistake of measuring the ability of employees to perform unstructured, unpredictable and uncertain job (Cook \& Crossman, 2004; Ismail et al., 2011, 2012b; Tahir Suliman, 2007; Thurston \& McNall, 2010). Under this new perspective, the use of political behavior by management in appraising employee performance is often seen as a crucial organizational climate factor where managers (appraisers) have not explicitly declared the use of political behavior in performance appraisals, but they will use their personal motives to manipulate performance scores when dealing with subjective and uncertainty job situations (Dulebohn \& Ferris, 1999; Ismail et al., 2011, 2012b; Poon, 2003a, 2003b, 2004). For example, managers will often decrease or increase performance scores in order to fulfill or protect their personal goals, particular individuals' interests, and/or certain groups' interests (Ferris \& Judge, 1991; Fried \& Tiegs, 1995; Murphy \& Cleveland, 1991). If managers use their skills to manipulate performance scores based on their positive interests this may motivate employees to support and accept the implementation of performance appraisal systems in organizations (Ismail et al., 2011, 2012b; Ferris \& Judge, 1991; Fried \& Tiegs, 1995).

According to organizational politic literature, many managers often implement two salient political behavior in appraising employee performance: motivational motive and punishment motive (Ismail et al., 2011, 2012b; Murphy \& Cleveland, 1991; Poon, 2003a, 2003b, 2004; Vigoda, 2000). Motivational motive is often defined the appraisers' personal agenda provide high performance ratings in order to stimulate, direct, and endure appraisees' behaviors to achieve organizational and/or departmental goals (Desimone et al., 2002; Ismail et al., 2011, 2012b; Poon, 2004). Conversely, punishment motive is usually defined as the appraisers' personal agenda assign low performance ratings in order to punish appraisees who have committed misconducts in order to correct their mistakes as well as increase their work disciplines (Ismail et al., 2011, 2012b; Poon, 2003, 2004; Ryness et al., 2002).

Unexpectedly, extant studies in organizational politics reveal that the ability of appraisers to properly use political motives in determining performance ratings may have significant impact on personal outcomes, especially job satisfaction (Ismail et al., 2011, 2012b; Poon, 2003a, 2003b), and job turnover (Ahmad et al., 2010; Gbadamosi \& Chinaka, 2011). In an organizational behavior perspective, job satisfaction is often defined as individuals like or dislike about their job and this feelings may induce positive and/or negative reactions toward their job in organizations (Ahmad et al., 2009; Locke 1976; Schermerhon et al., 2001). Conversely, job turnover is often interpreted as individuals intend to leave organization based on their choices (Dougherty et al., 1985; Gbadamosi \& Chinaka, 2011; Ismail et al., 2008, 2012a; Mobley, 1977, 1982). In a performance appraisal framework, many scholars think that motivational motive, punishment motive, job satisfaction and job turnover are different, but strongly interrelated concepts. For example, the ability of appraisers to properly use their motivational motive (i.e., intend to motivate employee performance) and punishment motive (i.e., intend to correct malpractices and improve work disciplines) in allocating performance scores may induce positive appraisee outcomes, especially increase job satisfaction (Ismail et al., 2011, 2012b; Poon, 2004; Vigoda, 2000), and decrease job turnover (Ahmad et al., 2010; Gbadamosi \& Chinaka, 2011).

Although the nature of this relationship is interesting, not much is known about the predicting variable of managers' political behavior in performance appraisal research literature (Ismail et al., 2011; Poon, 2003a, 2003b; Vigoda, 2000). Many scholars argue that the role of managers' political behavior as an important predicting variable has been given less emphasized in previous performance appraisal studies because they give more attention on the characteristics of performance appraisal politics, employ a simple correlation method to assess general respondent attitudes to performance appraisal types, and fail to elaborate the effects of managers' political behavior on personal outcomes in performance appraisal politics models. Consequently, the knowledge drawn from the studies provide inadequate guidelines that may not help practitioners to formulate effective action plans to handle internal and external performance appraisal problems in agile organizations (Ismail et al., 2011, 2012b; Poon, 2004; Tahir Suliman, 2007; Thurston \& McNall, 2010). Therefore, it motivates the researchers to fill in the gap of the literature by examining the relationship between managers' political behavior and personal outcomes.

\section{LITERATURE REVIEW AND HYPOTHESIS}

\section{Relationship between Performance Appraisal Politics and Personal Outcomes}

Several studies were conducted to investigate the effectiveness of performance appraisal politics using different samples, such as 303 public sector employees in Israel (Vigoda, 2000), 127 employees 
from various organizations in Malaysia (Poon, 2003a), 208 Malaysian employees from diverse occupations and organizations (Poon, 2003b), 60 employees from a private company in Sarawak (Ahmad et al., 2010), and 200 employees selected from Babcock University Ilishan in Nigeria (Gbadamosi \& Chinaka, 2011), and 150 employees in a national postal companies in Sarawak (Ismail et al., 2011). Findings from these studies show the ability of the management to properly implement motivational motive (e.g., intend to produce mutual benefits) and properly practice punishment motive (e.g., follow the correct rules and policies) in allocating performance scores had increased job satisfaction (Ismail et al., 2011, Poon, 2003a, 2003b; Vigoda, 2000), and decreased job turnover (Ahmad et al., 2010; Gbadamosi \& Chinaka, 2011).

These findings are consistent with the notion of motivation theory. For example, Skinner (1954) reinforcement theory, which reveals that positive reinforcer (e.g., recognition) and negative reinforcer (e.g., punishment) may affect individual behavior. Besides that, Adams' (1965) equity theory posits that fair or unfair treatment in allocating and exchanging resources may influence individual attitudes and behavior. Application of these theories in a performance appraisal model shows that the essence of motivational motivational motive and punishment motive is reinforcer and treatment. For example, the willingness of appraisers to appropriately implement motivational motive (e.g., have practiced communication openness, moral and mutual benefits) and punishment motive (e.g., have not practiced favoritism and biases) in determining performance ratings may lead to increased job satisfaction in organizations (Ismail et al., 2011, 2012b; Poon, 2003a, 2003b; Vigoda, 2000), and decreased job turnover (Ahmad $e t$ al., 2010; Gbadamosi \& Chinaka, 2011).

\section{Conceptual Framework and Research Hypothesis}

The literature serves as foundation of developing a conceptual framework for this study as illustrated in Figure 1.

\section{Independent Variable Dependent Variable}
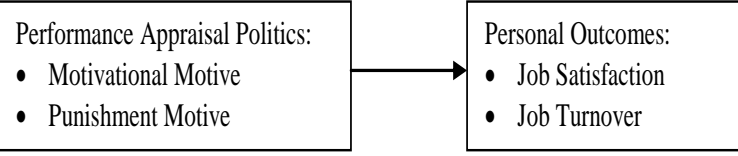

Figure 1. Relationship between Performance Appraisal Politics and Personal Outcomes
Based on the framework, it seems reasonable to assume that the willingness of managers to appropriately implement motivational and punishment motives in performance appraisal system will influence defence based university employees as this practice influences Western employees. Motivation theories further suggest that if defence based university employees view that their managers can properly implement motivational and punishment motives, this perception may lead to increase job satisfaction and decrease job turnover in the workplace. Therefore, it can be hypothesized that:

$\mathbf{H}_{\mathbf{1}}$ : There is a relationship between motivational motive job satisfaction

$\mathbf{H}_{2}$ : There is a relationship between punishment motive job satisfaction

$\mathbf{H}_{3}$ : There is a relationship between motivational motive and job turnover

$\mathbf{H}_{4}$ : There is a relationship between punishment motive and job turnover

\section{RESEARCH METHOD}

This study used a cross-sectional research method which allowed the researchers to combine the performance appraisal politics literature, the semi structured interview, the pilot study and the actual survey as the main procedure for data collection. The main advantage of using this method may decrease the inadequacy of single method and increase the ability to gather accurate, less bias and high quality data (Creswell, 1998; Ismail et al., 2011, 2012b; Sekaran \& Bougie, 2010). The location of this study was a defence based university, Malaysia. This university was newly established in 2007 to produce military officer cadets with academic qualifications, and civilian graduates with higher academic qualifications and basic defence skills. At the initial stage of data collection, the researchers begin with a semi structured interview that asking four issues: motivational motive in performance appraisal, punishment motive in performance appraisal, job satisfaction and job turnover. A purposive sampling technique was used to identify two experienced interviewees that is one human resource manager and one senior lecturer who have worked more than three years in the organization. They have adequate knowledge about the nature of performance appraisal politics practiced in the studied organization.

Next, the information gathered from the interviews were recorded, categorized according to the research variables, and constantly compared to the performance appraisal politics literature in order to obtain a clear understanding of the particular 
phenomena under study and put the research results in a proper context. The results of the triangulated process were used as a guideline to develop the content and format of survey questionnaires for a pilot study. Finally, a pilot study was done by discussing the pilot questionnaires with the interviewed participants. Their views were sought to verify the content and format of survey questionnaires for an actual survey. A back translation technique was used to translate the content of questionnaires in Malay and English languages in order to increase the validity and reliability of the instrument (Wright, 1996).

The survey questionnaire was divided into three sections. In the first, there were 4 items on motivational motive and 4 items on punishment motive, all were developed based on performance appraisal politics literature (Ismail et al., 2011, 2012b; Poon, 2003a, 2003b, 2004; Tahir Suliman, 2007; Thurston $\&$ McNall, 2010). In this section, respondents were asked questions on performance rating criteria, procedures and consequences. In the last section, job satisfaction had 10 items that were modified from job satisfaction scales (Ismail et al., 2008, 2011; Warr et al., 1979). In this section, respondents were asked to answer the questions about satisfaction with intrinsic and extrinsic job characteristics. Finally, job turnover had 6 items that were modified from job turnover literature (Ahmad et al., 2010; Kacmar \& Baron, 1999; North et al., 2005; Oparah \& Faloye, 2007). All the items used in the questionnaires were measured using a 7-item Likert scale ranging from "strongly disagree/dissatisfied" (1) to "strongly agree/ satisfied" (7). Information on demographic variables was used as a controlling variable because this study focused on employee attitudes.

The unit of analysis for this study is employees who have worked in a defence based university. Prior to conducting the survey, the researchers have obtained permission to conduct this study from the HR office of the studied organization. After considering the constraints of organizational rule, and the researchers' budgets and duration of study, 150 survey questionnaires were distributed using a convenience sampling technique to employees who work in every department in the organizations. Of the number, 78 usable questionnaires were returned, yielding 52 percent response rate. The number of sample met the acceptable standards for using inference statistics (Leedy \& Ormrod, 2005; Sekaran \& Bougie, 2010).

A Statistical Package for Social Science (SPSS) version 18.0 was used to analyse the psychometric of survey questionnaire data, and thus test the research hypotheses. The process begins with exploratory factor analysis to assess the validity and reliability of the measurement scales using Hair et al. (2006) and Nunally and Bernstein's (1994) guideline. Next, Pearson correlation analysis and descriptive statistics were performed to assess the validity and reliability of constructs (Hair et al., 2006; Nunally \& Bernstein, 1994). Finally, Stepwise regression analysis was used to quantify the magnitude and direction of many independent variables and one dependent variable (Foster et al., 1998; Hair et al., 2006).

\section{RESULTS AND DISCUSSIONS}

Table 1 shows the characteristics of participants in the studied organization. Majority respondents were male (56.2 percent), aged between 23 to 27 years old (42.5 percent), diploma holders (33.8 percent) and had working experiences less than 5 years (72.5 percent).

Table 1. Participant Characteristics ( $N=78)$

\begin{tabular}{lcr}
\hline $\begin{array}{c}\text { Respondent } \\
\text { characteristics }\end{array}$ & Sub -Profil & Percentage \\
\hline Gender & Male & 56.2 \\
& Female & 43.8 \\
\hline Age & $18-22$ & 5.0 \\
& $23-27$ & 42.5 \\
& $28-32$ & 31.2 \\
& $33-37$ & 8.8 \\
& $38-42$ & 5.0 \\
& $43-47$ & 5.0 \\
Education & $48-52$ & 2.5 \\
& SPM & 23.8 \\
& STPM & 12.5 \\
& Diploma & 33.8 \\
& Degree & 20.0 \\
& Master & 10.0 \\
\hline Length of Service & 0-5 years & 72.5 \\
& 6-0 years & 13.8 \\
& 11-15 years & 6.2 \\
& 21-25 years & 3.8 \\
& 26 years above & 3.8 \\
\hline
\end{tabular}

Note:

SPM/MCE: Sijil Pelajaran Malaysia/ Malaysia Certificate of Education (O-level)

STPM/HSC: Sijil Tinggi Pelajaran Malaysia/Higher School Certificate (A-level)

The exploratory factor analysis was employed to assess the psychometric of survey questionnaire data. Table 2 shows that the validity and reliability analyses of measurement scales. The survey questionnaires had 24 items which refer to three variables: motivational motive (4 items), punishment motives (4 items), job satisfaction (10 items), and job turnover (6 items). The validity and reliability analyses were 
conducted based on the procedures established by Nunally and Bernstein (1994) and Hair et al.(2006). A principal component factor analysis with oblique rotation using direct oblimin was first conducted to determine the possible dimensions of the constructs. Further, the Kaiser-Meyer-Olkin Test (KMO), which is a measure of sampling adequacy, was conducted for each variable. These statistical results showed that (1) all items for each variable had factor loading values of 0.5 and above, indicating that the items met the acceptable standard of validity analysis; (2) all research variables exceeded the minimum standard of Kaiser-Meyer-Olkin's value of 0.6 and were significant in Bartlett's test of sphericity, indicating that the sample was adequate to further conduct the factor and reliability analyses; (3) all research variables had eigenvalues larger than 1 and had variance explained larger than 0.45 , showing that the variables met the acceptable standard of validity analysis (Hair et al.,2006); and (4) all variables had alpha values greater than 0.70 , signifying that the variables met the acceptable standard of reliability analysis (Nunally \& Bernstein, 1994). These statistical results showed that the instrument used in this study met the acceptable standards of validity and reliability analyses as shown in Table 2 .

\section{Analysis of the Constructs}

Table 3 shows the Pearson correlation analysis and descriptive statistics. The mean values for the variables are from 3.0 to 5.2, signifying the levels of motivational motive, punishment motive, and job satisfactions ranging from moderately high (4) to highest level (7). The correlation coefficients for the relationship between the independent variable (i.e., motivational motive and punishment motive) and the dependent variable (i.e., job satisfaction dan job turnover) were less than 0.90 , indicating the data were not affected by serious collinearity problem (Hair $e t$ al., 2006). These statistical results further confirm the validity and reliability of the constructs used in this study as shown in Table 3.

\section{Outcomes of Testing Hypothesis 1 and Hypo- thesis 2}

Table 4 shows the outcomes of the stepwise regression analysis. It shows that demographic variables were entered in Step 1 and then followed by entering independent variables (i.e., motivational motive and punishment motive) in Step 2. Job satisfaction was used as the dependent variable. An examination of multi collinearity in the regression analysis shows that the tolerance values for the relationship between the independent variables (i.e., motivational motive and punishment motive) and the dependent variable (i.e., job satisfaction) were 0.95 and 0.94 , respectively. These tolerance values were more than the tolerance value of .20 (as a rule of thumb), indicating that the variables were not affected by multi collinearity problems (Fox, 1991).

Further, the table shows that the inclusion of motivativational motive and punishment motive in the analysis had explained 37 percent of the variance in dependent variable. Specifically, the results of testing research hypothesis using stepwise regression analysis showed two important outcomes: first, motivational motive and punishment motive positively and significantly correlated with job satisfaction $(\beta=.35$, $\mathrm{p}<0.01 ; \beta=.33, \mathrm{p}<0.01$, respectively), therefore $\mathrm{H} 1$ and $\mathrm{H} 2$ were supported. Statistically, this result confirms that managers' political behavior (i.e., motivational motive and punishment motive) have been important determinants of job satisfaction in the studied sample.

Table 2. The Results of Validity and Reliability Analyses for the Instrument

\begin{tabular}{lccccccc}
\hline \multicolumn{1}{c}{ Measure } & $\begin{array}{c}\text { No. of } \\
\text { Item }\end{array}$ & $\begin{array}{c}\text { Factor } \\
\text { Loadings }\end{array}$ & KMO & $\begin{array}{c}\text { Bartlett's Test } \\
\text { of Sphericity }\end{array}$ & Eigenvalue & $\begin{array}{c}\text { Variance } \\
\text { Explained }\end{array}$ & $\begin{array}{c}\text { Cronbach } \\
\text { Alpha }\end{array}$ \\
\hline Motivational motive & 4 & 0.51 to 0.70 & .78 & $452.17 \mathrm{P}=0.000$ & 4.64 & 46.42 & 0.87 \\
Punishment motive & 4 & 0.62 to 0.85 & .81 & $146.25 \mathrm{P}=0.000$ & 2.89 & 72.14 & 0.85 \\
Job satisfaction & 10 & 0.54 to 0.93 & .77 & $144.61 \mathrm{P}=0.000$ & 2.78 & 69.55 & 0.94 \\
Turnover & 6 & 0.83 to 0.1 & 0.86 & $426.87, \mathrm{p}=0.000$ & 4.64 & 77.30 & 0.94 \\
\hline
\end{tabular}

Table 3. Pearson Correlation Analysis and Descriptive Statistics

\begin{tabular}{lcccccc}
\hline \multicolumn{1}{c}{ Variable } & Mean & Standard Deviation & \multicolumn{3}{c}{ Pearson Correlation Anaysis } \\
\hline 1. Motivational Motive & 5.2 & 1.1 & 1 & 2 & 3 & 4 \\
2. Punishment Motive & 5.1 & 1.2 & $.51^{* *}$ & 1 & & \\
3. Job Satisfaction & 5.0 & 1.1 & $.49^{* *}$ & $.48^{* *}$ & 1 & \\
4. Turnover & 3.31 & 1.58 & -0.122 & 0.002 & -0.06 & 1 \\
\hline
\end{tabular}

Note: Significant at $* * \mathrm{p}<0.01$

Reliability estimation is shown diagonally (value 1) 
Table 4. Results for Stepwise Regression Analysis

\begin{tabular}{lcc}
\hline \multicolumn{1}{c}{ Variables } & \multicolumn{2}{c}{$\begin{array}{c}\text { Dependent Variable } \\
\text { (Job Satisfaction) }\end{array}$} \\
\cline { 2 - 3 } Control Variable & Step 1 & Step 2 \\
\hline Gender & & \\
Age & -.12 & -.08 \\
Education Level & -.13 & -.12 \\
Length of Service & -.08 & -.17 \\
Independent Variable & .23 & .23 \\
Motivational Motive & & \\
Punishment Motive & & $.35^{* *}$ \\
R Square & & $.33^{* *}$ \\
Adjust R Square & .05 & .37 \\
R square change & -.01 & .32 \\
F & .05 & .33 \\
F $\Delta$ R Square & .86 & $6.96^{* * *}$ \\
\hline No: Significant at & .86 & $18.32^{* * *}$ \\
\hline
\end{tabular}

Note: Significant at $* * * p<0.001$

\section{Outcomes of Testing Hypothesis 3 and Hypo- thesis 4}

Table 5 shows the outcomes of the stepwise regression analysis. It shows that demographic variables were entered in Step 1 and then followed by entering independent variables (i.e., motivational motive and punishment motive) in Step 2. Job turnover was used as the dependent variable. An examination of multi collinearity in the regression analysis shows the relationship between the independent variables (i.e., motivational motive and punishment motive) and the dependent variable (i.e., job turnover) were 0.94 and 0.94 , respectively. These tolerance values were more than the tolerance value of .20 (as a rule of thumb), indicating that the variables were not affected by multi collinearity problems (Fox, 1991).

Table 5. Results For Stepwise Regression Analysis

\begin{tabular}{lcc}
\hline \multirow{2}{*}{\multicolumn{1}{c}{ Variables }} & \multicolumn{2}{c}{$\begin{array}{c}\text { Dependent Variable } \\
\text { (Job Turnover) }\end{array}$} \\
\cline { 2 - 3 } & Step 1 & Step 2 \\
\hline Control Variable & & \\
\hline Gender & -.06 & -.06 \\
Age & -.06 & .03 \\
Education Level & .02 & -.55 \\
Length of Service & -.11 & -.84 \\
Independent Variable & & \\
Motivational Motive & & -1.42 \\
Punishment Motive & & 1.48 \\
R Square & .03 & .06 \\
Adjust R Square & -.03 & -.02 \\
R square change & .03 & .04 \\
F & .46 & .77 \\
F $\Delta$ R Square & .46 & 1.39 \\
\hline Not Sqgifican & &
\end{tabular}

Note: Significant at $* * * p<0.001$
Further, the table shows that the inclusion of motivational motive and punishment motive in the analysis had explained 1 percent of the variance in dependent variable. Specifically, the results of testing research hypothesis using stepwise regression analysis showed two important outcomes: first, motivational motive and punishment motive insignificantly correlated with job turnover ( $\beta=-1.42, \mathrm{p}>0.05$; $\beta=1.48, p>0.05$, respectively), therefore $\mathrm{H} 3$ and $\mathrm{H} 4$ were not supported. Statistically, this result confirms that managers' political behavior (i.e., motivational motive and punishment motive) have not been important determinants of job turnover in the studied sample.

\section{Discussion}

The findings of this study confirm that managers' political behaviour have played important roles as determinants of job satisfaction, whereas managers' political behaviour have not played important roles as determinants of job turnover in the organizational sample. In the context of this study, HR managers and/or managers have been used the standardized policies and rules set up by the stakeholder to determine equity in performance appraisal systems. In the administration of performance appraisal systems, the majority of the employees perceived that the levels of motivational motive, punishment motive and job satisfaction are high, but the level of job turnover is moderately high. In this situation, the implementation of motivational and punishment motives in allocating performance scores have increased employees' job satisfaction, but the implementation of motivational and punishment motives in allocating performance scores have not decreased employees' job turnover in the organizational sample.

There are three major implications of this study: theoretical contribution, robustness of research methodology, and practical contribution. In terms of theoretical contribution, the findings of this study reveal two important findings: first, motivational motive and punishment motive have played important roles as an important determinant of job satisfaction. This result is consistent with the studies by Vigoda (2000), Poon (2003a, 2003b), and Ismail et al. (2011, 2012). Second, motivational motive and punishment motive have not played important roles as an important determinant of job turnover. A careful observation of the semi-structured interview results reveals that this finding may be affected by the culture of public service sector environments. Firstly, majority respondents have different feelings of importance about the implementation of managers' 
political behaviour in determining their performance scores. Second, majority respondents have inconsistent judgements about the capability of managers to fairly practice political behaviour allocating their performance scores. These factors may overrule the effectiveness of managers' political behaviour in decreasing job turnover in the studied organization.

With respect to the robustness of research methodology, the survey questionnaires used in this study have exceeded the acceptable standards of the validity and reliability analyses. This could lead to the production of accurate and reliable research findings. In terms of practical contribution, the findings of this study could serve as guidelines by HR managers to improve the administration of performance appraisal systems in organizations. The important aspects should be considered are: firstly, soft skill training modules for managers need to be properly planned in order to enhance their abilities in practising interpersonal communication, counselling, ethics and problem solving techniques when allocating performance scores to employees who work in different job classifications. Secondly, appraisers and appraises needs to be encouraged to implement participation in making appraisal decisions may increase employees' understanding and decrease their misjudgements about the performance appraisal systems. Thirdly, top management needs to be given autonomous power to department heads in order to enable them appropriately design performance appraisal measurements that suit with their departments' goals, needs and expectations. Fourthly, a performance appraisal committee at organizational level needs to be established in order to check and moderate the performance appraisal evaluations and reports that are made by different backgrounds of department heads and supervisors. This practice may decrease mistakes and increase the validity and reliability of performance measurement systems. Finally, recruitment and selection policies need to be changed from hiring fresh university graduates who do not have adequate knowledge and experiences to knowledgeable and experience employees in order to fulfil supervisory and managerial positions. If these suggestions are highly given attention, this may strongly motivate employees to support and accept the implementation of performance appraisal systems in organizations.

\section{CONCLUSIONS AND RECOMMENDATIONS}

This study proposed a conceptual framework based on the performance appraisal politics research literature. The exploratory factor analysis confirmed that the measurement scales used in this study met acceptable standards of validity and reliability analyses. Further, outcomes of testing research hypothesis using a stepwise regression analysis showed two important findings: first, managers' political behavior (i.e., motivational and punishment motives) did act as important determinants of job satisfaction in the studied organization. This result has also supported and broadened performance appraisal politics literature mostly published in Western countries. Second, managers' political behavior (i.e., motivational and punishment motives) did not act as important determinants of job turnover in the studied organization. A thorough review of the semi-structured interview results reveals that this result may be affected by the culture of public service sector environments. Firstly, majority respondents have different feelings of importance about the implementation of managers' political behaviour in determining their performance scores. Second, majority respondents have inconsistent judgements about the capability of managers to fairly practice political behavior in allocating their performance scores. These factors may overrule the effectiveness of managers' political behaviour in decreasing job turnover in the studied organization.

Therefore, current research and practice within the performance appraisal politics model needs to consider both motivational and punishment motives as crucial dimensions of the workplace performance management domain. This study further suggests that the capability of management to appropriately practice motivational and punishment motives in allocating performance scores will strongly induce positive attitudinal and behavioral outcomes (e.g., performance, commitment, trust and acceptance). Thus, these positive outcomes may lead to sustained and increased organizational performance in an era of global competition.

The conclusions drawn from this study should consider the following limitations. First, a crosssectional research design used to gather data at one time within the period of study might not capture the causal connections between variables of interest. Second, this study does not specify the relationship between specific indicators for the independent variable and dependent variable. Third, the outcomes of stepwise regression analysis have only focused on the level of performance variation explained by the regression equations, but there are still a number of unexplained factors that affect the causal relationship among variables and their relative explanatory power (Cohen \& Cohen, 1983; Tabachnick \& Fidel, 2001). Finally, the sample for this study was taken from one institution of higher learning that allowed the 
researchers to gather data via survey questionnaires. These limitations may decrease the ability to generalize the results of this study to other organizational settings.

The conceptual and methodological limitations of this study should be deliberated when planning future study. First, several organizational and personal characteristics should be further explored, as this may provide meaningful perspectives for understanding how individual similarities and differences affect the managers' political behavior within an organizational performance appraisal system. Second, other research designs (e.g., longitudinal studies) should be used to collect data and describe the patterns of change and the direction and magnitude of causal relationships between variables of interest (Leedy \& Ormrod, 2005; Sekaran \& Bougie, 2010). Third, to fully understand the effect of managers' political behavior on work attutides and behavior, more organizations need to be used in future study. Fourth, other specific theoretical constructs of managers' political behavior such as communication, participation, support, and justice need to be considered because they have widely been recognized as an important link between managers' political behavior and personal outcomes (Ahmad et al., 2009; Ismail et al., 2012a, 2012b; Salimaki \& Jamsen, 2010). Fifth, response bias and common-method variance is a common issue in all questionnaire-based research. Therefore, the inclusion of a larger sampling pool in future research would decrease bias in gathering data and this could lead to produced better results (Creswell, 1998; Sekaran \& Bougie, 2010). Finally, other personal outcomes of personal outcomeslike commitment, performance, turnover, stress and fairness should be considered given their prominence in performance appraisal politics research literature (Ismail et al., 2012a; Pettijohn et al., 2001; Sabeen \& Mehbob, 2008; Salimaki \& Jamsen, 2010). The importance of these issues needs to be further elaborated in future research.

\section{REFERENCES}

Adams, J. S. 1965. Inequity in Social Exchange. In Berkowitz, L. (Eds.), Advances in Experimental Social Psychology, New York: Academic Press.

Ahmad, R., Lemba, C. \& Wan Ismail, W. K. 2010. Performance Appraisal Politics and Employee Turnover Intention. Journal of Humanities, 16: 99-109.

Ahmad, Z. A., Surienty, L., Effendi, A. A. Jauhar, J. Rohaida, S. \& Sharma, T. 2009. Understanding Organizational Behavior. Kuala Lumpur: Oxford University Press.
Aminuddin, M. 2008. Human Resource Management: Principles and Practices. Kuala Lumpur: Oxford University Press.

Boswell, W. R. \& Boudreau, J. W. 2002. Separating the Developmental and Evaluative Performance Appraisal Uses. Journal of Business and Psychology, 16: 391-412.

Cohen, J. \& Cohen, P. 1983. Applied Multiple Regression/Correlation Analysis for the Behavioral Sciences. Hillsdale, NJ: Erlbaum.

Cook, J. \& Crossman, A. 2004. Satisfaction with Performance Appraisal System: A Study of Role Perceptions. Journal of Managerial Psychology, 19: 526-541.

Creswell, J. W. 1998. Qualitative Inquiry and Research Design: Choosing Among Five Traditions. London: SAGE publications.

Dulebohn, J. H. \& Ferris, G. R. 1999. The Role of Influence Tactics in Perceptions of Performance Evaluations' Fairness. Academy of Management Journal, 42: 288-303.

Desimone, R. L., Werner, J. M. \& Harris, D. M. 2002. Human Resource Development. New York: Harcourt, Inc.

Dessler, G. 2005. Human Resource Management. New Jersey: Pearson Education Upper Saddle River.

Dougherty, T. W., Bluedorn, A. C. \& Keon, T. L. 1985. Precursors of Employee Turnover: A Multiple Sample Casual Analyses. Journal of Occupational Behavior, 6: 259-271.

Ferris, G. R. \& Judge, T. A. 1991. Personnel/Human Resources Management: A Political Influence Perspective. Journal of Management, 17: 447488.

Fletcher, C. 2001. Performance Appraisal and Management: The Developing Research Agenda. Journal of Occupational and Organizational Psychology, 74: 473-487.

Foster, D. P., Stine, B. \& Waterman, R. 1998. Business Analysis Using Regression: A Casebook. Springer-Verlag.

Fox, J. 1991. Regression Diagnostic. Thousand Oaks, California: Sage Publications

Fried, Y. \& Tiegs, R. B. 1995. Supervisors' Role Conflict and Role Ambiguity Differential Relations with Performance Ratings of Subordinates and the Moderating Effect of Screening Ability. Journal of Applied Psychology, 80: 28291.

Gbadamosi, L., \& Chinaka, N. J. 2011. Organizational Politics, Turnover Intention and Organizational Commitment as Predictors of Employees' Efficiency and Effectiveness in Academia. A 
Paper presented in the Informing Science \& IT Education Conference (InSITE) 2011, 305-314.

Hair, J. F., Anderson, R. E. Tatham, R. L. \& Black, W.C. 2006. Multivariate Data Analysis. New Jersey: Prentice Hall International, Inc.

Ismail, A., Ishak, M. S., Kuching, W. \& Omar, M. 2008. Hubungan Sikap kepada Wang dan Kepuasan Kerja terhadap Keinginan Pekerja untuk Berhenti secara Sukarela: Kajian di Sebuah Organisasi Pihak Berkuasa Tempatan Berstatus Bandaraya di Sarawak. Jurnal eBangi, 3 (1), 1-19.

Ismail, A., John, C., Boerhannoeddin, A., Md Rasip, O. \& Wan Ismail, W.K. 2012. Kepuasan Kerja adalah Peramal kepada Keinginan Berhenti Kerja secara Sukarela: Satu Kajian di Sebuah Penguasa Tempatan. Jurnal Kemanusiaan, 19:11-26.

Ismail, A., Najib, A. M. \& Arshad, M. M. 2012. Linking Political Behavior in Performance Appraisals to Distributive Justice As a Determinant of Job Satisfaction. International Business Management, 6(2): 109-118.

Ismail, A., Zainol, N. A. M. \& Najib, A. M. 2011. An Empirical Study of the Relationship between Performance Appraisal Politics and Job Satisfaction. Acta Universitatis Danubius. Economia, 7(1): 5-19.

Kacmar, K. M., \& Baron, R. A. 1999. Organizational politics: The State of the Field, Links to Related Processes, and an Agenda for Future Research. Research in Personnel and Human Resources Management, 17: 1-39.

Leedy, P. D. \& Ormrod, J. E. 2005. Practical Research: Planning and Design. New Jersey: Pearson Education Ltd.

Locke, E. A. 1976. The Nature and Causes of Job Satisfaction. In Dunnette, M. D. (Eds.), Handbook of Industrial and Organizational Psychology (pp. 1297-1349). Chicago IL: Rand McNally.

Mobley, W. H. 1977. Intermediate linkages in the Relationship between Job Satisfaction and Employee Turnover. Journal of Applied Psychology, 62(2): 237-240.

1982. Employee Turnover: Causes, Consequences, and Control. Reading, MA: AddisonWesley.

Murphy, R. T. \& Cleveland, J. N. 1991. Performance Appraisal: An Organizational Perspective. Boston, MA: Allyn and Bacon.

North, N., Rasmusson, E., Hughes, F. \& Finlayson, M. 2005. Turnover amongst Nurses in New Zealand District Health Boards: A National Survey of Nursing Turnover and Turnover Cost. Journal of Employment Relation, 30-49.
Nunally, J. C. \& Bernstein, I. H. 1994. Psychometric Theory. New York: McGraw-Hill.

Oparah, O. B. \& Faloye, J. O. 2007. Influence of Occupational Stress and Organizational Politics on Turnover Intention among Selected Industrial Workers in Ibadan. Ogun Journal of Counseling, 1(1): 9-16.

Pettijohn, C., Pettijohn, L. S., Taylor, A. J. \& Keillor, B. D. 2001. Are Performance Appraisals a Bureaucratic Exercise or Can they be Used to Enhance Sales-Force Satisfaction and Commitment? Psychology and Marketing, 18: 337-64.

Poon, J. M. L. 2003a. Situational Antecedents and Outcomes of Organizational Politics Perceptions. Journal of Managerial Psychology, 18: 138-155.

2003b. Situational Antecedents and Outcomes of Organizational Politics Perceptions. Journal of Managerial Psychology, 18(2): $138-155$.

2004. Effects of Performance Appraisal Politics on Job Satisfaction and Turnover Intention. Journal of Managerial Psychology, 33: 322-334.

Ryness, S. L., Brown, K. G. \& Colbert, A. E. 2002. Seven Common Misconceptions about Human Resource Practices: Research Findings versus Practitioner Beliefs. Academy of Management Executive, 36: 577-600.

Sabeen, Z. \& Mehbob, A. A. A. 2008. Perceived Fairness of and Satisfaction with Employee Performance Appraisal and Its Impact on Overall Job Satisfaction. The Business Review, Cambridge, 10(2): 185-192.

Salimaki, A. \& Jamsen, S. 2010. Perceptions of Politics and Fairness in Merit Pay. Journal of Managerial Psychology, 25(3): 229-251.

Schermerhon, J., Hunt, J. G. \& Osborn, R. N. 2001. Organizational Behavior. Asia: John Wiley \& Sons.

Sekaran, U., \& Bougie, R. 2010. Research Methods for Business: A Skill Building Approach. New York: John Wiley \& Sons.

Skinner, B. F. 1954. Science of Learning and the Art of Teaching. Havard Educational Review, 24: 86-97.

Tabachnick, B. G. \& Fidell, L.S. 2001. Using Multivariate Statistics. Sydney: Allyn \& Bacon.

Tahir Suliman, A. M. 2007. Links between Justice, Satisfaction and Performance in the Workplace: A Survey in the UAE and Arabic Context. Journal of Management Development, 26(4): 294-311 
Thurston, P. W. \& McNall, L. 2010. Justice Perceptions of Performance Appraisal Practices. Journal of Managerial Psychology, 25(3): 201228

Vigoda, E. 2000. Organizational Politics, Jobs Attitudes, and Work Outcomes: Exploration and Implications for the Public Sector. Journal of Vocational Behavior, 57: 326-347.
Warr, P. B., Cook, J. \& Wall, T. D. 1979. Scales for the Measurement of Some Work Attitudes and Aspects of Psychological Well-Being. Journal of Occupational Psychology, 52: 129-148.

Wright, I. L. 1996. Qualitative International Management Research. In Punnett, B. J \& Shenker, O. (Eds.), Handbook for International Management Research (pp. 63-81). Oxford, UK: BlackWell Publishers Inc. 